JOURNAL

OF URBAN

SOCIETY'S ARTS

Volume 7 Nomor 2,

October 2020: 94-108

\section{Islam, National, and Local History in Tabbhuwan Walisanga Performance Art}

\author{
Panakajaya Hidayatullah
}

Fakultas Ilmu Budaya, Universitas Jember

Jl. Kalimantan No. 37, Jember, Jawa Timur

Email: panakajaya.hidayatullah@gmail.com; HP.: +628990523702

\begin{abstract}
Tabbhuwân is a Madurese tradition of performing arts. In the present context, modern culture influences many young people. It has become a restlessness for the clerics who then think of strategies on how to incorporate Islamic values in the younger generation today. In 2015 in Situbondo, Wali Sanga boarding school established a tabbhuwân wali sanga art group. Tabbhuwân is considered a way of preaching according to the conditions and culture of the community of Madura Situbondo. The players consist of the santri of the younger generation of Islamic boarding schools. Tabbhuwân wali sanga features Islamic drama performances that elevate the play of Islamic history and Indonesia. The play included Islamic history (stories of the companions of the Prophet Muhammad), local history, the history of the entry of Islam on Java (walisanga), and the history of Indonesian independence, one of which was titled 'Jihad Resolution.' Besides, tabbhuwân also includes elements of Madurese culture, including language, traditional music, expression, decoration, and discourse. Tabbhuwân plays a role in the spread of Islam, preserving Madurese culture and instilling nationalism in society through historical themes. The lower-middle-class community assumes that tabbhuwân is a means to understand the historical, social, and cultural realities occurring today. Tabbhuwân also influences fostering a sense of nationalism through heroic historical values, especially to the younger generation. In this case, tabhuwân imagines Indonesia in the discourse of religious nationalism.

Keywords: Tabbhuwân; Madurese performing art; Wali Sanga Boarding School
\end{abstract}

\begin{abstract}
ABSTRAK
Islam, Nasional, dan Sejarah Lokal dalam Seni Pertunjukan Tabbhuwan Walisanga. Tabbhuwân adalah seni pertunjukan tradisi masyarakat Madura. Dalamkontekskekinian, budaya modern banyak mempengaruhi kaum muda. Hal ini menjadi keresahan para ulama yang kemudian memikirkan strategi bagaimana memasukkan nilai-nilai Islam pada generasi muda saat ini. Pada tahun 2015 di Situbondo, Pondok Pesantren Wali Sanga mendirikan kelompok seni tabbhuwân wali sanga. Tabbhuwân dianggap sebagai cara dakwah yang sesuai dengan kondisi dan budaya masyarakat Madura Situbondo. Para pemainnya terdiri dari para santri generasi muda pondok pesantren. Tabbhuwân wali sanga menampilkan pertunjukan drama Islam yang mengangkat lakon sejarah Islam dan Indonesia. Lakon tersebut meliputi sejarah Islam (cerita para sahabat Nabi Muhammad), sejarah lokal, sejarah masuknya Islam di Jawa (walisanga), dan sejarah kemerdekaan Indonesia, salah satunya bertajuk 'Resolusi Jihad'. Selain itu, tabbhuwân juga memasukkan unsur budaya Madura yang meliputi bahasa, musik tradisional, ekspresi, ragam hias dan wacana. Tabbhuwân berperan dalam penyebaran agama Islam, pelestarian budaya Madura dan menanamkan nasionalisme dalam masyarakat melalui tema sejarah. Masyarakat kelas menengah ke bawah menganggap tabbhuwân sebagai cara memahami realitas sejarah, sosial dan budaya yang terjadi saat ini. Tabbhuwân juga memiliki pengaruh dalam menumbuhkan rasa nasionalisme melalui nilai-nilai sejarah yang heroik, khususnya kepada generasi muda. Dalam hal ini, tabhuwân membayangkan Indonesia dalam wacana nasionalisme agama.
\end{abstract}

Kata kunci: Tabbhuwân; seni pertunjukan Madura; Pondok Pesantren Wali Sanga 


\section{Introduction}

Tabbhuwân is a term generally used by Madurese people in Situbondo to call any art performance. Bouvier (Bouvier, 2002, p. 62) explains that tabbhuwân is a term used to call gamelan, set of gamelan and gamelan performance. In Madurese language, tabbhuwân means tabuhan (beat). Madurese people have wider and more complex meaning of this word which is art performance. Tabbhuwân, specifically, is usually used to call genre of Madurese traditional performance art which uses gamelan instruments in its show such as tabbhuwân Topeng Kertè, tabbhuwân Loddrok and tabbhuwân Katoprak. A genre of performance art which doesn't use gamelan like Al Badar drama using western and dangdut music instruments is distinguished to call orkes.

In Situbondo with majority of Madurese people (Husson, 1997), tabbhuwân still exists and lives today. The most popular genre among them is tabbhuwân Katoprak/Madurese Ketoprak. There are rombongan (groups) of tabbhuwan Katoprak in Situbondo from Madurese island and Situbondo such as groups of Rukun Karya and Rukun Famili from Sumenep Madura; Sinar Famili, Putra Famili, Rukun Sejati, Karya Famili, and Rantai Alam from Situbondo. All the groups commonly have similar format of performance. The differences are just music style and players. Rombongan is a local term used by Situbondo people to call an art group.

In 2015, there is a group tabbhuwân Katoprak which is different to others that is tabbhuwân Wali Sanga group (for further abbreviated TWS). TWS was founded in 8 March 2015 by Kiyai Kholil, As'ad. K.H. Kholil As'ad is a head of Wali Sanga Islamic boarding school in Situbondo. Institutionally, TWS is an organization run by Wali Sanga Islamic boarding school. TWS has clear vision of preaching and spreading Islam. Different to others tabbhuwân Katoprak, TWS is not commercial. All operational and production cost of its show is charged to Kyai. They call it 'invitation' not 'order'. They usually receive sincere fees from its host like Waris said as a script writer and director of TWS:

"TWS aims to serve people's needs like when there is celebration like kenduren, selametan of village, wedding, maulid nabi (the prophet Muhammad birthday), national celebration etc. TWS is a way of preaching and spreading Islam by means of media that is close to people. It has a duty to ngobâi èberrâ masyarakat sè biasana lèbur ningghu maksiat (change people's taste who like immoral things). The Kyai uses a name tabbhuwân Wali Sanga to make it familiar to people" (Waris, Personal Communication, $14^{\text {rh }}$ July 2018).

Waris statement shows that TWS exists as a strategy by the Kyai to change people's taste who like immoral things to be better by means of TWS educative performance. In case of stories, conventional tabbhuwân Katoprak have historical stories like babad, legend, history of Mataram kingdom and others kingdoms. In TWS, its stories focus on Islam history: stories of prophet Muhammad's companions; national history: Jihad resolution and Diponegoro war; and local history: history of Bawean, Madura, history of local figure, history of Wali Sanga and spread of Islam in Java. All the stories are based on context of spreading Islam. Decision to take historical theme is very important for Kyai as many young generation today do not know Islam, national and local history. Although, they learn history in formal school, but in fact, many young people are illiterate to history. They think of history lesson in school is boring and strict as its method just memorize names of figures, events and years from books (Waris, Personal Communication, $14^{\text {rh }}$ July 2018).

A story usually played is adjusted to motive, moment and location of performance. As an example, TWS holds its show in Palangan Jangkar with wedding moment, so a story is adjusted to wedding which is history of prophet Muhammad's companion entitled "The Most Beautiful Jewel of God - a story of Syeikh Abu Bakar Al Basshar". Location of performance is also considered. First, Kyai will observe social phenomena in the location then it is analyzed and decides an appropriated story. For instance, if there are many divorces and infidelities in that local environment. So TWS will have the story of Syeikh Said bin Musayyad which tells guidance to choose future good son and 
daughter in law according to Islam. Besides, when there are bad boys who disobey their parents in that place, TWS will have a story of Uwais Al Qurni which tells lesson and exemplary of the prohet's companion who is dutiful to parents. These are some historical stories often played in Situbondo: history of Islam which are: Uwais Al Qurni, Salman Al Farisi, Hasyim Al Bashar, Syeikh Said bin Musayyad, Abu Bakar Al Basshar, Ashabul Kahfi dan Bilal; national history which are Diponegoro war and Jihad resolution; local history which are Adi Podây Adi Rasa, spread of Islam to Bawean and Syeikh Maulana Ishaq.

\section{Method}

This article is a result of qualitative research which uses ethnography method which specifically focuses on stories with historical theme of TWS performance art. In discussion, the stories text analyzed are limited to three stories which are story of Salman Al Farisi that represents history of Islam, story of Jihad Resolution that represents national history and story of Syeikh Maulana Ishaq that represents local history. The discussion will focus on 1) adaptation of form and culture in historical stories, 2) historical values in the stories, 3) Tabbhuwân as media of conveying history education.

\section{Adaptation of Form and Culture in Historical Stories of Tabbbuwan Walisanga}

TWS changes some of conventional form of Madurese tabbhuwân Katoprak performance. Those changes are duration, form of music, use of modern technology and stories. Its duration is about 2-3 hours long, which is different to common tabbhuwân show playing all night long (about $08.00 \mathrm{pm}$ to $04.00 \mathrm{am}$ ). Its duration also changes structur of its performance. Conventional tabbhuwân commonly consists of three parts/ rounds which begin from traditional dance, joke and play/drama story. TWS packs it to one round of performance with jokes and play, except dance does not perform in TWS performance. Jokes scene is not separated from its story, they are united.
Besides, form of music TWS play is very different to common tabbhuwân. Its music is more dynamic and adapts popular rhyme of young generation like rock, pop, dangdut, koplo and hadrah. Musically, they do not follow standard of Madurese karawitan. It becomes new form of music, fresh and creative in style of young santri. TWS becomes adaptive to contemporary era as they use modern technology in their performance like using clip on microphone, advanced lighting and sound effect. These kinds of efforts can be said to be efforts to defend the cultural values that exist in traditional arts, given that the progress of the times demands changes in the patterns of performing arts. Some of these patterns are also practiced in many performing arts genres such as wayang beber (Nurcahyono, 2018). In order to examine the issue of adaptation of form and culture in TWS, the following will describe the historical stories presented by TWS,

\section{The Truth Hunter - Salman Al-Farisi}

'The Truth Hunter - Salman Al-Farisi' is a title of history of Islam story in TWS performance which tells struggle of a prophet Muhammad's companion who seek for religion's truth. This story is usually played in moment of celebration of prophet Muhammad's birthday as its story depicts more about the prophet Muhammad. Besides, Salman story also shows sacrifice of the prophet's companion who persists to seek a true religion. Here is a brief story of Salman taken from a script of TWS performance.

The story begins from Salman family in Isfahan city, Persia. Salman lives in high class and rich family. His family is Majusi believers as well as religious Salman. Some day Salman meets a group of Christian people from Syiria who pray to church. Salman gets interested to learn that religion as he thinks that it is better than his family's religion. But his father is disappointed with his attitude who disobeys his ancestral religion. Salman is then punished by being chained and is not feeded for three days. Salman then succeds to escape with help of his father's maid. He then 
succeeds to fulfill his wish to learn Christian religion with a pastor in Syiria.

Salman is persistent and discipline to learn until the pastor dies. Salman is then given a guidance to continue his lerning to some pastors recommended by his first pastor. Salman then learns to some pastors until the fifth/the last pastor.

After the fifth pastor dies, Salman is finally given guidance to continue his wandering to a country flanked by two cities where date palms flourish and there are many black stones. A place where there is a prophet sent to bring the truth with prophetical signs on his back. Salman then continues his journey by hitchhiking and paying golds to a group of merchants going to Madinah. Unfortunately, Salman is tricked and then sold to infidel master in Madinah. During his time and life as slave, Salman gets severe tortured.

Until some day, he hears his master speaking about a man claimed as prophet and has appaled Madina land. With full of spirit, Salman seek a chance to meet the prophet secretly. He finally meets the prophet Muhammad and then states to convert to Islam in front of him. The prophet sends Salman to set his free from slavery, but he always fails.

Until then, the prophet and his companions collect cost to compensate him in amount of $40 \mathrm{oz}$ golds and 300 date palm trees. Salman then gets free and join the prophet. Salman becomes an important companion and has big contribution to the winning of Khandaq war.

The story ends when Salman is getting old and asked by his companions to tell process of him to meet the prophet Muhammad. In short, Salman then praises the prophet until he cannot hold his tears and then he faints. His companions then also feel his compassion and feel that the prophet is still with us to guide to the way of truth (Summarized and re-narrated from a reading of strory script of Salman Al-Farisi by TWS).
That is a summary of Salman Al-Farisi story TWS plays. Before the story is played, it needs long and complex creative process.

The creative process begins from seeking reference and literature which discuss history of Islam about the prophet's companions. In case of Salman Al-Farisi story, Waris as the writer uses some Islam literature which are books entitled Rijalu Khoilir Rasul and Characteristics of Life of Sixty Companions of the Prophet (Khalid, 2006) arranged by Khalid Muh. Khalid. Besides, as basic of the story, Waris also refers to Al Quran, Hadist, Barzanji book and words from Kyai. By means of these references, Waris is doing his creative process and translating them to story script (Waris, Personal Communication, $14^{\text {rh }}$ July 2018). A ready script is then given to Kyai to do Tashih (corrected and reiewed its data by Kyai Kholil As'ad).

Writing a strory to be a script is a new creative process for Madurese traditional tabbhuwân. Tabbhuwân players commonly memorize core of a story and make improvisation in a stage without script. The form of theater per-

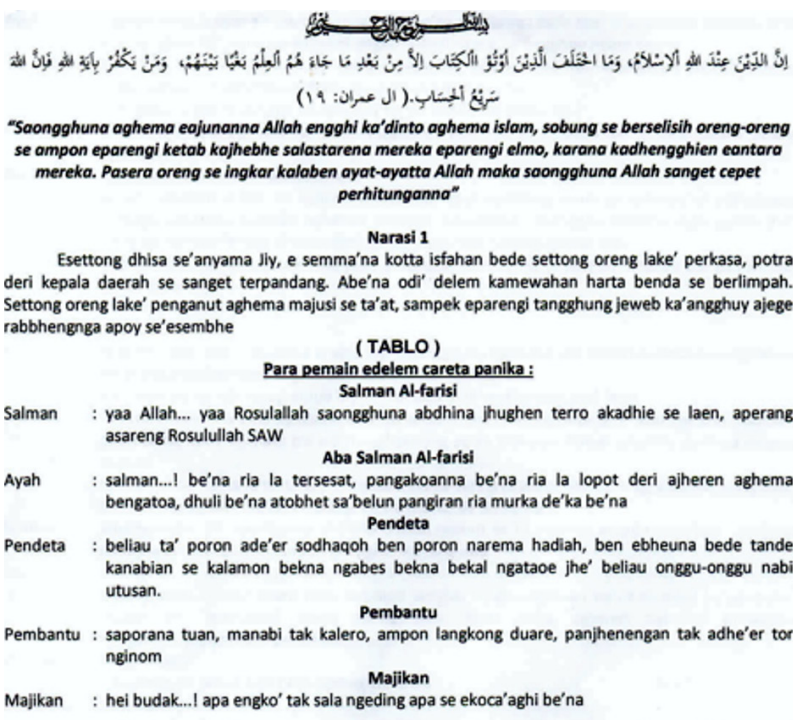

Naaah... tantaretan sadheje peristiwa ponapa se adheddhleghi kaodianna aobe, ka'angghuy gaoningi ngireng arengsareng kita sakse'e Kisah perjalanan "SANG PEMBURU KEBENARAN, SALMAN ALFARISI"

Esettong are se sanget cerah, Salman eparentah sareng abana ka'angghuy mareksa perkembangan (a) salman nangale kaum nasrani se pa'reppa'na ngalakoni ibede neng e gereja, rassa terro oninga se aghudhe atena aghebey dhibi'na ajhelen nojihu de' ngalakoni 'bede neng e gereja, rassa terro oninga se aghudhe atena aghebey dhibi'na ajhelen nojijhu de' saengghe dhibl'na nganggheb ben arassa yakin Jhe' saongghuna aghema mereka se lebbi bheghus deri aghema se' toro' salman samulae. Saengghe esettong malem terjadi peristiwa se'aghebey sakabbhinna aobe.$$
\text { Babak } 1
$$

Salman sudah ditengah panggung
Salman : nasrani, nasrani iye aria aghema se detenga deri syiria, sa'ellana sengko' ngabesseghi cara mereka aibede ma' rassana aghemana mereka se lebbi bheghus deri aghema se etoro' sengko'

Figure 1. Story Script of Salman Al-Farisi. Source: Waris. 
formance, which departs from a drama script and is then performed in a theater format with a ketoprak nuance, is actually not something new in the world of Indonesian performing arts (Kurniawan, 2016), however, for performances in areas such as Situbondo where most of the performances are still in a cultural format, this kind of performance is still relatively new. Here is an example of a story script of Salman Al-Farisi written by Waris.

Story script accepted by Kyai is then performed in form of drama. The ready drama script is not automatically permitted to perform in front of audience. Like a script which is corrected by Kyai, drama performance is also having a process of Tashih by Kyai. After all the process is done, so its performance is permitted to perform in front of people.

From the explanation above, there is process of adaptation of form and culture in TWS in story of Salman Al-Farisi. Adaptation is a kind of translation, transculture and transform from a kind of art to another art. In wider meaning, adaptation is also understood as process of changing a kind of science to be an art work (Damono, 2012, p. 1). In case of TWS, a kind of adaptation becomes creative strategy of artist to make historical story more alive and easier to interpret by people. In story of Salman Al-Farisi, there is a process of transmedia of conveying story message from written text, holy book, Quran, hadist and books to be form of drama/ performance art.

The story of Salman Al-Farisi begins from historical text scattered among many source of literature. Waris collect it and then re-interpret it to be a new creative text which is drama script. An event to transform scientific historical text to creative text is a process of the firs adaptation in story of Salman Al-Farisi. In the beginning of Salman Al-Farisi story, it quotes a verse of Al

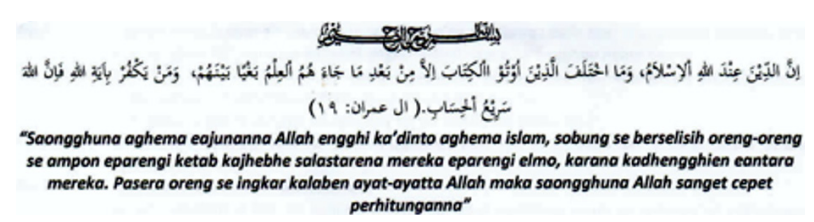

Figure 2. A verse of Al Quran in the opening of TWS story script. Source: Waris.
Qur'an related to the story which also becomes basic of its historical theme (Figure 2).

Qur'an text then becomes a basic which drives how its next story goes. When there is a scene of $\mathrm{Al}$ Qur'an recitation, there is no any performance in stage. The stage is closed with curtain which is then spotlighted by projector which displays the Al Qur'an text. The Al Qur'an verse and its translation in Madurese language is red by a narrator under the stage (Figure 3).

An event of displaying Al Qur'an text in story script to the stage performatively is a process of second adaptation. It also shows use of multimedia. The Al Qur'an text is not only displayed but also red by a narrator with music illustration of Kitaro which actually has completely different context to meaning of the Al Qur'an verse. But its process of multimedia usage finally can strengthen a message meaning of Al Qur'an text. An event of combining kinds of sign in art is called creative indexing as explained by Thomas Turino (Turino, 1999).

After reciting a Qur'an verse which becomes its basic story, it continues to drama scenes. The performance of drama scenes is actually an adaptation of text book and a book which tells Salman Al-Farisi story. Besides, some hadist and content of Barzanji books are strengthening message of its historical story. Barzanji is a book which praises the prophet Muhammad. Its content is used to depict a figure of the prophet Muhammad as told again by Salman Al-Farisi and his companions at the end of the story. The drama scenes of Salman Al-Farisi are using multimedia packed in a such way by a director and writer to strengthen a message of the story.

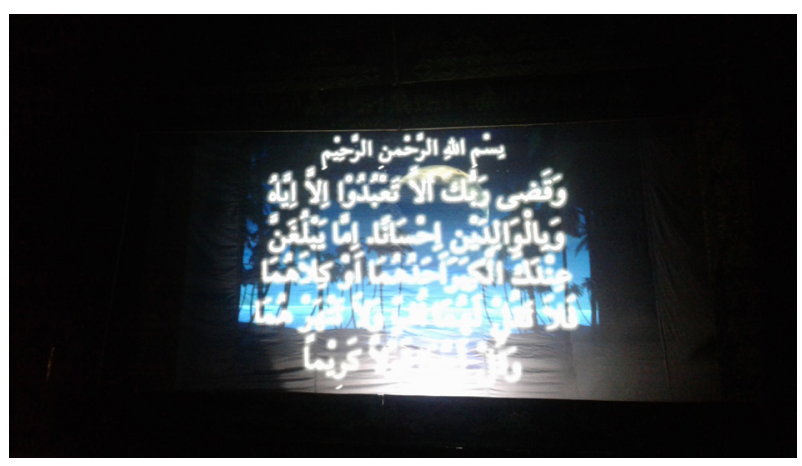

Figure 3. A display of Al Qur'an text in TWS stage. Source: Hidayattulah. 
Besides adaptation, Salman Al-Farisi story in TWS is also having trasculture. Transculture is a process of translation of culture from a work with a certain cultural background to another culture. According to Damono (Damono, 2012, p. 31), "translation is actually a practice to change a way of expression in certain culture to another cultural expression”. This also means that there is transformation of code/sign which is adjusted to aimed culture.

As explained in a summary of the story, this story has Middle-East cultural background (Persia-Arab). Middle east culture should be performatively actualized by using Arab language, Middle-East clothes and Middle-East setting at that time. Instead of changing its cultural signs, TWS is doing transculture to Madurese-Indonesian culture. The story of Salman Al-Farisi is performed by using Madurese language with Indonesian costume (cap/kopyah, sarong, batik, Hansip/police uni-form and Indonesian clothes). Its setting of time is complicated between the past and the present (Figure 4).

Use of Indonesian costume is recommended by Kyai to make audience, Madurese people, easier to receipt and interpret its cultural symbols. Its point which want to convey is a message, not its form, so that its process of transculture is possible to do. There is an exception in use of costume for main characters. They wear clothes like Middle-East costume to differ between common people and Syeikh/ cleric. Here is what Kyai said as stated by Waris.

"There is an advice from Kyai, Islam shows Middle-East costume, Middle-East people and then the Kyai said: "enjâ" ta' papa jârèya

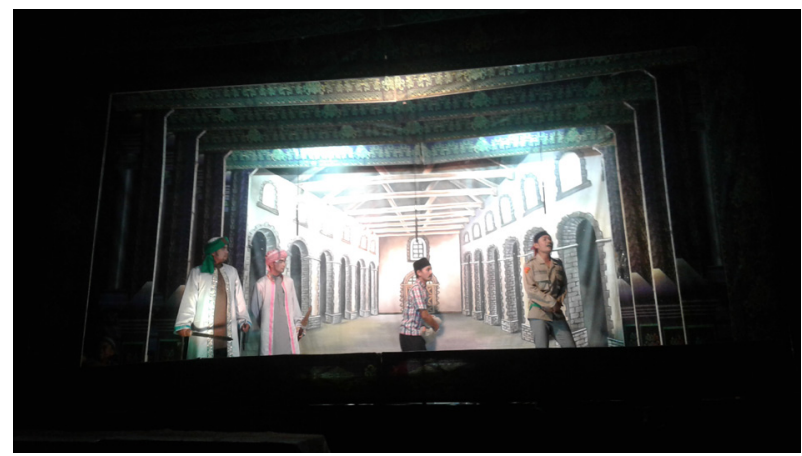

Figure 4. Transculture in TWS performance. Source: Hidayattulah. kostumma ke-Indonesiaan, tak rapa" (It is not problem to use that costume, that is Indonesian people costume). Can you imagine that if all players are wearing Middle-East costume, wearing turban? Indonesian people will think that they are all kyai. That is the reason. So there will be a difference between Syeikh and not Syeikh" (Waris, Personal Communication, $10^{\text {rh }}$ November 2018).

Process of transculture does not only happen in form of drama but also its accompaniment music. Its music is Madurese gamelan music played with modern rhyme, (pop, rock, dangdut, koplo and hadrah, which are popular to people. Syïir or lyric is created by Kyai by using Madurese language and adjusting it to context of a story. Illustration music is also used as backsound which is not MiddleEast music but compilation of Kitaro instrumental music. It also uses instrumental music which is popular in Indonesia, Deen Assalam.

\section{NU Jihad Resolution - A Drop of Dew in the Middle of Badlands}

'NU Jihad Resolution - A Drop of Dew in the Middle of Badlands' is a title of story with historical theme in TWS performance. The story tells about resistance of santri in Indonesian indepence war in Surabaya. The story is often performed in moments of national days like $17^{\text {th }}$ August, santri day and hero day. The story of Jihad Resolution in TWS performance is played with 12 rounds/parts. Here is a brief description of NU Jihad Resolution in TWS performance.

The story of Jihad Revolution begins from a story of Republic of Indonesian independence in 17 August 1945. Although Indonesia proclaimed its independence, but people's struggle was not finished yet. Not even a month the word Independence echoed, Indonesia was facing crucible. Right on $15^{\text {th }}$ September 1945, thousands of English armies included in AFNEI came to Indonesia followed by Dutch armies called NICA. They came to restore Dutch East-Indies government as they did not acknowledge Indonesian independence. 
The first round in this story begins from conversation between Kusno and Markesot, people of Surabaya, talking about the coming of Dutch armies in Surabaya. They worried of the Dutch coming and began to be furious to fight as soon as possible. The second round is illustrating a Dutch high official and an English army. Ploegman ordered armies to fly the Dutch flag in Yamato hotel. This event then caused enmity. Young people of Surabaya with Sudirman opposed the Dutch action until a conflict happened and took lives. Finally, the Dutch flag succeded to tear apart and change to Indonesian redwhite flag. That event was finally heard to Bung Karno until that made him worry and anxious with increasing tense conditions.

The third part tells about Bung Karno's anxiety as said to Bung Hatta. They then agreed to seek help from Hadratus Syeikh KH. Hasyim Asyari. Through an adjudant who was sent, Bung Karno conveyed a secret mandate to the Kyai which contains, "What is the law to defend a homeland? Not defending Allah, not Islam or Al Qur'an, again defending a homeland". The fourth part tells about a meeting between Bung Karno's adjudant and KH. Hasyim Asyari. In short, Kyai had accepted Bung Karno's mandate and then he discussed Bung Karno's intention with Kyai Wahab and Kyai Bisri. The fourth and the sixth rounds tell about discussion between the three Kyais. They then agreed to make fatwah: a law to defend homeland is a must for every moslem in a radius "Musyafotus Safar" which is $94 \mathrm{~km}$ from enemy's position. They underlied it with Al Qur'an verse, Al Qur'an surah An-Naml, verse 34. Finally they spread the fatwa jihad to all people around. The fatwa was written in pegon letter so that the Dutch would not recognize it. In $21^{\text {st }}-22^{\text {nd }}$ October 1945, Kyai from Java and Madura held a conference about an effort to defend Indonesian independence. A result of the conference was then known as NU Jihad Resolution.

The seventh and eighth rounds tell about struggle of Suroboyo people that reminds Bung Tomo that Kyais have taken a firm decision in this difficult situation. The flaring Bung Tomo then asked permission to his mother to join people to defend the homeland and soon he would go to meet $\mathrm{KH}$. Hasyim Asyari before having speech in front of people of Suroboyo. The nineth round tells about Bung Tomo asking permission and blessing from Kyai Hasyim Asyari before having speech. Kyai did not give him permission before first he straightened his intention. Kyai entrusted him to begin and end his speech with praising God by saying Allahu Akbar. In $30^{\text {th }}$ October 1945, there was an event causing a tension which was General Mallaby killing by resistance of a santri from Tebu Ireng.

The killing of Mallaby made Brithish and Dutch armies furious (in tenth round). A leadership of the armies was then taken by Lieutenant General Christison. He threatened Indonesian people with ultimatum until $06.00 \mathrm{am}$ in $10^{\text {th }}$ November 1945 , asking Indonesian people to surrender and hand over all their weapons unless the British would mobilize all military power to burn down the ground. The eleventh round tells about Bung Tomo's monumental speech who can flame spirit of Suroboyo people. British armies began to bomb buildings of Surabaya government and mobilized 30.000 infantries, numbers of fighter planes, warships and tanks to burn down the city of Surabaya. The war lasted for three weeks. The city of Surabaya was burnt down. The allies lost the best 2 generals and 2.000 armies. About two hundered thousand people of Surabaya who were women and children evacuated outside the city and Indonesian side lost sisty thousand lives.

The end of the story is in twelveth round which tells about Kyai Hasyim Asyari speech about jihad values in Islam, meaning of struggle and love for the motherland (Summarized and renarrated from a reading of the story script NU Jihad Resolution TWS). 
The story script of Jihad Resolution is a result of long creative process. Like other historical stories which must be corrected by Kyai, the script Jihad Resolution has the same process as its data must be valid before performing it to people. When writing the script, Waris uses some different methods from the story of Salman AlFarisi. Primary data are taken from interview and words from some Kyais as Kyais are considered to be key informants who understand historical problem of Jihad Resolution. Its secondary data are taken from scientific books like Jihad Resolution: Kyai Struggle from upholding Religion to Nation (Bustami, 2015) and The Most Syar'I Jihad Resolution (Guyanie, 2010). Besides, Warsi and writers team of TWS story interview the script writer of Sang Kyai film in Surabaya and adapt some scenes of Sang Kyai film in TWS performance.

A performance form of Jihad Resolution story is also having a process of adaptation of form and culture. Process of adaptation in

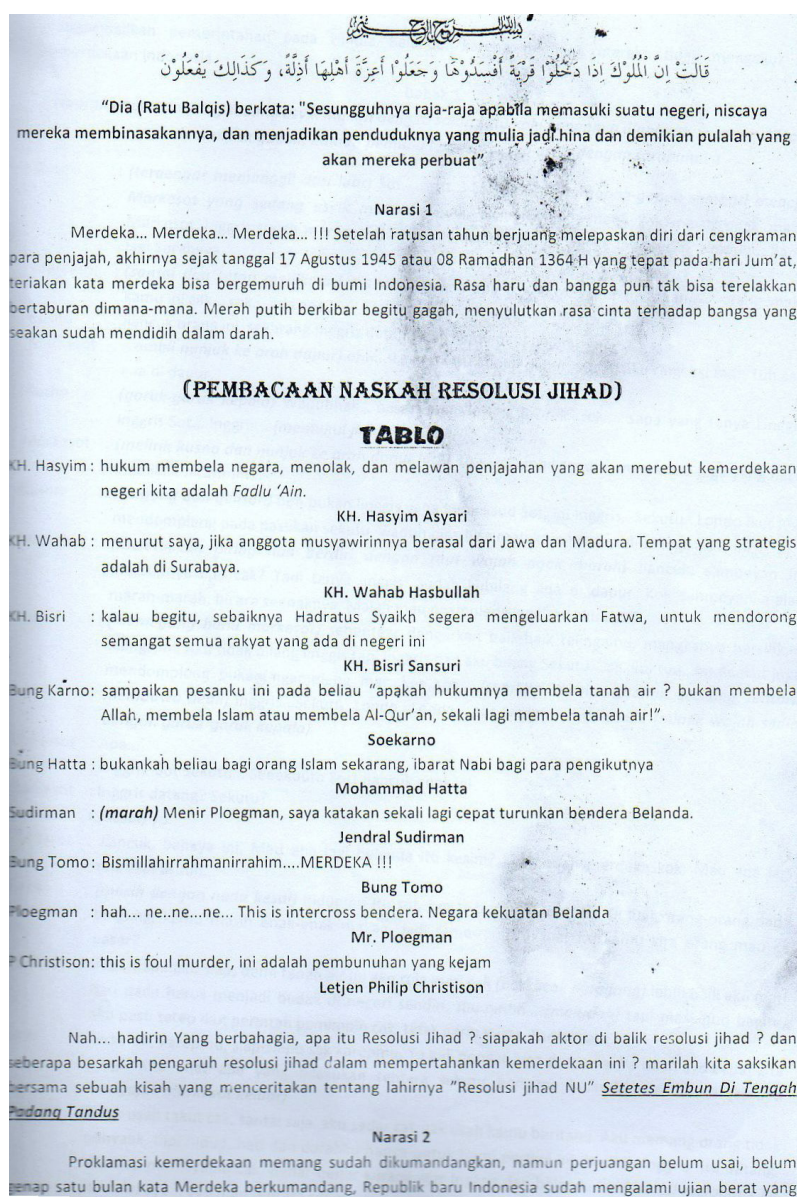

Figure 5. The story script of NU Jihad Resolution. Source: Waris. this story is different to Salman Al-Farisi story. Especially for this story, Waris chooses to refer oral sources from Kyai Kholil As'ad as primary reference. It then adds other scientific books as references. This process shows that there is transformation from oral source to story script. The story script also transforms to multimedia as a result of interpretation of historical books. The story script is then adapted to be drama performance.

In its performance, forms of TWS multimedia in the story of Jihad Resolution are the same as story of Salman Al-Farisi, that combine many media like music, singing, visual, drama and technological elements of audio recording. Technological elements of audio recording are used when scene of Bung Tomo reading his speech. In that scene, its audio is not from a player reading the speech in stage but it is taken from original audio recording of Bung Tomo when reading his speech.

A kind of adaptation of culture in Jihad Resolution story can be found in its drama performance. It is known that cultural context of that story is Javanese culture in Surabaya. In fact, TWS is doing transculture to be Madurese culture. Waris is writing the story of Jihad Resolution by using Indonesia and Javanese language adjusted to cultural context in Surabaya.

Indonesian language is used to make players easier to memorize the dialogue when playing in front of non-Madurese people. Jihad Resolution has ever been performed by using Indonesian language in some places like Banyuwangi, Jember and Surabaya. When

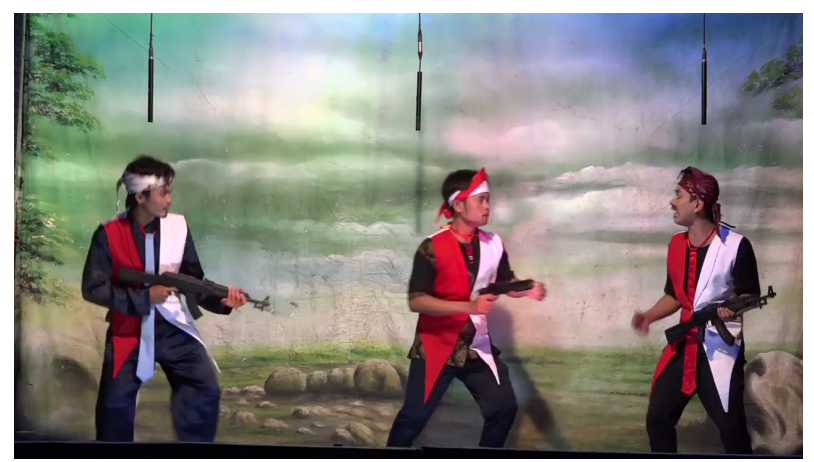

Figure 6. Transculture in TWS performance, characterization of Betawi, Java and Madura. Source: Hidayatullah. 
audience is Madurese majority, the performance will have transculture to be Madurese (Figure 5).

In form and structure, performance of the story of Jihad Resolution is the same as Salman Al-Farisi's which begins with $\mathrm{Al}$ Quran recitation as basic of its historical story. It continues to players introduction and then the story begins. In Situbondo, they play this drama by using Madurese language, Madurese music and Madurese cultural expression. While in costume and characterization, TWS makes them plural and diverse. Its costume is not dominated by Madurese clothes but there are also elements of batik and Indonesian clothes like cap, shirt and attributes of clothes with red and white symbol. Elements of its characterization are made more plural and complex by involving freedom figters from Jakarta, shown in their Betawi dialect, and Java, shown in Javanese dialect.

The script of Jihad Resolution is having creative process of transculture which is very flexible in stage. As improvisations of Ketoprak performance, a script is also not rigidly followed by players. So its multimedia forms certainly exist in its performance in stage.

\section{The Coolness Carrier - Syeikh Maulana Ishaq}

The Coolness Carrier - Syeikh Maulana Ishaq is a title of historical and local story performed by TWS. The story tells about spreading Islam in Blambangan by means of a marriage between Syeikh Maulana Ishaq and Blambangan princess, Dewi Sekardadu. They then have a son Sunan Giri, one of The Wali Sanga. This story is usually played in a moment of wedding as its story also tells about marriage between Syeikh Maulana Ishaq and Dewi Sekardadu. Here is a brief description of Syeikh Maulana Ishaq story from TWS script.

The story of Syeikh Maulana Ishaq begins from Blambangan kingdom in epidemic situation. The princess Dewi Sekardadu gets infected. The contagious epidemic makes the King, Menak Sembuyu worry and then he asks hand of the king, Bajul Segoro to hold competition to heal Dewi Sekardadu as asked by the queen. A winner, if it is a man, will be awarded to marry Dewi Sekardadu and gets position as hand of the king. When a winner is a girl, she will be a new princess of the kingdom. After going quite long, the competition has not succeded to find a winner. Dewi Sekardadu is not healed yet from the disease. Finally, the epidemic news is heard by a brahmana, Resi Kandabaya. The resi comes to the king and asks the king to look for somebody in Gresik mountain. He is going to heal Dewi Sekardadu disease. The king then sends hand of the king, Bajul Segoro, to look for him and asks him to heal the princess.

The hand of the king with groups then go to Gresik mountain by riding horse for six days long. Arriving at Gresik mountain, he then meets Syeikh Maulana Ishaq and asks him to heal Dewi Sekardadu. After thinking, Syeikh accepts Bajul Segoro's request. The hand of the king and group ask Syeikh to go together to Blambangan, but Syeikh denies and asks Bajul Segoro to go first. He will go after him. The hand of the king then goes with group to Blambangan. On the same day, Syeikh has already been in Blamangan.

In short, Syeikh is accepted by the king and asked to immediately heal his daughter. The king is confused as Syeikh does not bring any potion or medicine. Syeikh just only shalat with two round and prays to ask cure to Allah. Finally, Syeikh succeeds to heal the princess and the king keeps his promise to marry Dewi Sekardadu with him. Not only healing the princess, Syekh then heals all Blambangan people. Marriage of Syeikh and Dewi Sekardadu is held for a week. In sixth day of the wedding celebration, the hand of the king, Bajul Segoro and group arrive at Blambangan. He is confused with crowded situation in the kingdom. The hand of the king seeks information from servants. $\mathrm{He}$ does not believe the situation that happens. How is it possible that suddenly Syeikh has married while he just arrives from long journey. The hand of the king then meets the king and Syeikh. He is confused and does not 
believe of what is happening in Blambangan in that fast time. The more days pass, Syeikh gets more followers of Islam. The hand of the king begins to worry of his position which is soon taken by Syeikh. The hand of the king incites the king to drive Syeikh away with a reason that Syeikh will disobey the king. The frantic king caused by the hand incitement finally drives Syeikh away from Blambangan land. Syeikh hardly follows the king's order and leaves Dewi Sekardadu who is preganant in Blambangan.

After Syeikh leaving, Blambangan land gets attacked by epidemic again. The king becomes confused with this difficult situation in the kingdom. The hand of the king then accuses that the epidemic is coming from a baby in the womb of Dewi Sekardadu. The hand of the king gives advice to the king to kill his grandchild going to be born. But Dewi Sekardadu has heard his evil plan. Before that happens, Dewi Sekardadu escapes from the kingdom and brings the baby in the box to

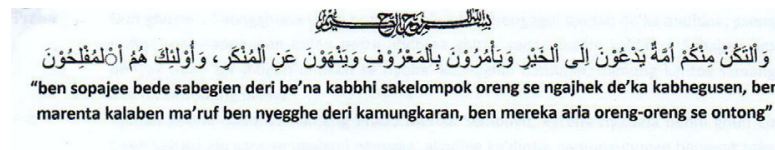

Narasi 1

Sunan-sunan Wali Songo ekenal sebagai penyebar Islam neng e abad $14 \mathrm{M}$. Wali Songo aropaagh simbol penyebaran Islam neng e Indonesia. Sanajjen bennyak ujien tor rintangan se kodhu e adhebhi para sunan, namung kalaben kamantepan ate tor cita-cita luhur, sadhejena beliau adhebbhi tor jhugen tak loppa kaanghhui teros nyoon pertolongan de'ka Se Maha Kobesa. Akadhie se alami sareng penyebar Islam e periode pertamana berjasa neng e awal kadetenganna namung kodhu kaloar deri istana demi aje cope tak tejali peruma bherkat kobesa deri Ghuste beliau bisa apanghi sareng potra kandunga tor sami-sami berjuang kaangghu nyebaraghi aghema Islam.

$\begin{gathered}\text { Para pemain dalam cerita ini: } \\ \text { Syekh Maulana Ishaq }\end{gathered}$
Syekh $\quad$ : rassana sengko' lakar sakodhuna nyingla deri tempat rea
Prabu Menak Sembuyu

Nah... tan-taretan sadheje, paserah tokoh penyebar Islam se e maksod ? ujian ponapa se kodu beliau adhebi ? tor ponapa se ealami potra beliau saampona lahir delem kabedeen jheu deri abana ? ngireng areng-sareng kita sakse'e settong careta se nyaretaaghi tentang tokoh penyebar Islam Nusantar Sang Pembawa Kesejukan, Syekh Maulana Isha

Narasi 2

Maha socce Allah se ampon adheddhiaghi bintang-bintang e langngi' tor jhugen adheddhiagh mataare tor bulen kalaben cahayana, se adheddhiaghi malem tor siang ate-ghente kaangghui oreng se asajhhe kaangghui mondhut pelajaran otabe se asajijhe kaangghui asyokkor. Sapanika kaodien se teros aghente, tak salanjhenga bhumi bhekal terang, tor kadheng bhumi jhugen petteng, manussa tak salanihenga bhekal ngalami kahungaan, tor kadheng manussa jhugen ngalami kasossaan. Tor kasossa Teter, tor putus asa. Termasok jhugen keluarga istana, mereka jhugen ngalami kasossaan amarghe Dewi Sekardadu potre epon prabu menak sembuyu raja blambangan jhugen dheddhi korban deri panyake' panika Babak 1

Raja Blambangan bersama Patih Bajul sedih melihat Sang Putri tergolek lemah di depannya

Figure 7. Story script of Syeikh Maulana Ishaq. Source: Waris. the sea like the prophet of Moses story. In the middle of the sea, the baby is founded by group of merchants from Gresik who are bringing goods to Bali. When the baby in the box is carried to ship, the ship stops. As the group is panic, they then go back to Gresik with a baby of Syeikh and Dewi Sekardadu. Arriving at Gresik, the group is rebuked by Nyi Ageng Pinatih as their master as they cannot bring goods to Bali. The merchants tell what happen in the sea that they find a baby. As a woman, Nyi Ageng Pinatih who is longing to have a baby is finally excited and willing to take care of the baby. She then names him, Joko Samudro. Joko Samudro is growing and begins to learn Islam under guidance of Sunan Ampel in Surabaya. He then becomes a wali with a name Sunan Giri.

The story ends with describing a chaotic condition of Blambangan kingdom that gets inevitable contagious epidemic The king has lost his loving grandson and daughter. Finally, the king asks Bajul Segoro to be responsible for the chaos he makes in the kingdom. The king then realizes and regrets of what he has done. Now he must accept a harsh reality in his kingdom.

The story script of Syeikh Maulana Ishaq is a result of creative process by Waris as the script writer. In that story, Waris uses oral source from Kyai (words of Kyai) as main reference. He thinks that Kyai has more knowledge about life journey of Syeikh Maulana Ishaq (Figure 7).

Like a creative process of Jihad Resolution, process of adaptation in the story of Syeikh Maulana Ishaq also begins from oral text (Kyai

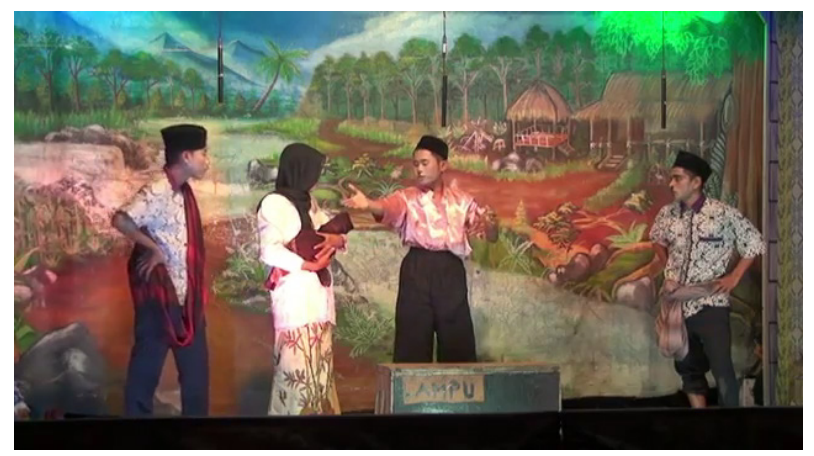

Figure 8. Transculture in the story of Syeikh Maulana Ishaq. Source: Hidayatullah. 
words) which are re-interpreted by Waris and then written in story of Syeikh Maulana Ishaq. From the making process to its performance, it is generally having the same process which is a step tashih by Kyai. Its drama performance is not much different with the two other stories as explained before which is having adaptation of form to be a text with multimedia.

Process of transculture also happens in this story. Cultural background in this story is Javanese, Gresik and Blambangan, Banyuwangi. Situbondo was a part of Blambangan kindom (Arifin, 2008, p. 147), but now it has different culture to Banyuwangi. Therefore transculture becomes very possible in this story although this story is considered to be local story. In its performance, it is used Madurese language, Madurese song, lyric and Madurese expression. But in costume, TWS adjusts various culture in Indonesia. These are costumes of players in the story of Syeikh Maulana Ishaq.

\section{Cultural and Historical Values in Stories by Tabbhuwan Wali Sanga}

Value is something very important for human and people in a culture which is related to everything good and bad, and guidance for living together. According to Clyde Kluckhohn and Florence Kluckhohn (Koentjaraningrat, 1990, p. 77), every system of culture has a set of abstract concepts which has a wide scope and lives in people's mindset about what is important and valuable in life. Therefore, set of values in a culture is guidance and orientation of life for all human behavior.

In TWS, there are cultural and historical values expressed in a story performed and they still have a content relevant to modern and contemporary era. Max Scheler classifies values to be four levels of hierarchy: 1) pleasure values are realated to pleasure and displeasure in objects; 2 ) vital values are related to vitality of life; 3) spiritual values are related to aesthetic (beauty-bad), truth (true-wrong) and values of sincerely pure knowledge; 4) values of the Holy are related to absolute, sacred and profane objects (Bertens, 1983; Jizarnah, 2018, p. 90).
TWS performance contains pleasure values which entertain people. TWS performance is for pleasing people's desire, healing their fatigues, recreation and reflection of reality of people's life. Pleasure values can be seen from audience reception when responding statements, dialogues and jokes by TWS characters of a story. In Madurese people, experience of watching a performance which rises pleasure and presents aesthetic experience is usually expressed by a term lèbur (very exciting). Audience response is actualized by diverse expression and audience behavior when watching a performance. In jokes scene, some jokes characters speak Madurese pantun which contains jokes and satire as follows:

Joker: Mellè kalambi bânynya' kembhângnga (buying floral shirt)

Ding la èleppèt èsabầ ka lamarina (after being folded up, put it in ardrobe)

Rèng akalowarga ria bunga biasana (someone with family is usually happy)

Mara kancana jhầ pamèlo sossana (come on, do not make your friends sad)

In the middle of speaking pantun, audience cheers the jokes characters spontaneously with words "siiih", "siada" and other expression with laughing together. Throughout the story, audience actively respond the story performed. If there is something they do not wish, they will respond by expressing to stage. As an example, there is a scene of Syeikh Abu Bakar Al Bashar who marries Aisha. In that scene, Syeikh wants to hug and kiss Aisha's eyebrow. When the scene of kissing, there are audience cheering up and being touched. On the other hand, there is a teenager who cheer and tease his friend next to him by saying, "Aii... Aii... Boh... Boh... Sih... Sih... Budi terro kia Budi ria" (Budi also wants to do it). Other audience then cheer up and laugh. Characters' voices get lower and covered by audience's cheers. When TWS is performing, there is almost no distance beween performers and audience as throughout performance, audience also make unique situation by expressing words and characters will respond them back as if they were not separated by the high of stage. Spontaneous reactions usually emerge when a theme or statement said by actors in a stage touches life of people around in form of unique 
satire of their local environment, hotnews or satire to government. In this case, as if audience found an alternative way to release their desire, experience and problems by watching TWS performance.

Vital values are related to patriotic values in historical stories of TWS performance. Patriotic values can be felt in certain moments in every story which is performed by TWS, for instance a struggle of santri who defend the homeland and Indonesian independence in the story of Jihad Resolution. How is santri role who cannot stay silent while their country is ruined by British and Dutch armies. In the story of Jihad Resolution, Kyai Hasyim can be a role model as a religious figure who cannot stay silent looking East Java people being trampled by the Dutch. In this difficult situation, he finally makes decision to fight and does not stay silent waiting for good fortune. Besides, Bung Tomo can also be an iconic figure in the story. By his flaming spirit and his heroic speech, he then can rise patriotic spirit of Surabaya people in battlefield. Through these heroic figures, it is hoped to be inspiration for audience, especially young people. Therefore TWS as educative media of Islamic boarding house can keep to carry out its mission to fill Indonesian independence and spread nationalism values to wide community.

Spiritual values are related to beauty and mental elements in TWS performance. Spiritual values manifest in TWS performance by presenting complexity and deep feeling of audience. Spiritual values are also shown in artistic of performance which makes it different to conventional method of spreading religious values like sermon. Spiritual values are related to mental building taken from characters in story performance. A kind of mental to be an exemplary for people is like Salman Al Farisi's mental who has persistence to seek the truth. Although, he must pay it with pain of torture and punishment, being humiliated by people, being slaved, Salman keeps firm and persists to study to seek for the truth. While there is also a bad mental which must be avoided by people as depicted in a hand of the king, Bajul Segoro, in the story of The Coolness Carrier in which Bajul Segoro is depicted as a hater, someone with prejudice and crazy of power.
The last, religious values are related to educative values and spiritual values in historical stories of TWS performance which contain moral and educative messages for people. Educative values are pedagogic to give information and exemplary to people. Educative values in historical stories of TWS performance are teaching people about persistence and strong will to seek the truth, being patient to face crucible and holding firm principles of life like in story of Salman Al-Farisi. Spiritual values in historical stories are the main things in TWS performance. This can be seen and felt in moments of reciting shalawat nabi and Al Quran, with players' dialogue which all aims to internalize spiritual values of Islam. As an example, every transition of performance scene always contains recitation of shalawat and syi ir Islam in Madurese language.

"Sèra ta' terro apolonga bân Nabi, sèra ta" terro apolonga bân Nabi, para sahabat padâ akorban kabbhi, para sahabat padâ akorban kabbhi, salamet ontong baginda Nabi, salamet ontong baginda Nabi, duh kanjeng Nabi"

(Who are among you who do not want to be with the prophet? who are among you who do not want to be with the prophet? All the prophet's companions has sacrificed, all the prophet's companions has sacrificed, ya the prophet)

According to Waris, TWS is actually not only performance to entertain people, but also shalawat activities. Shalawat is not only in form of recitation but also it can be interpreted in other forms like TWS performance (Waris, Personal Communication, $14^{\text {th }}$ July 2018). Madurese people in Situbondo call and interpret spiritual experience in shalawat by the term "Asambhung dầ Rosulullah" (get in touch with the prophet). That concept of spirituality is shown in stories of the prophet's companions.

\section{Tabbhuwan as Media to Convey History Education}

Kyai is worried about a condition of young generation today. Modern culture has changed 
behavior of young people to be destructive. Kyai overcomes it by giving education through TWS performance. Before that, Kyai also thinks that performance of tabbhuwân Katoprak only spread immoral things like gambling, drunk, performing sensualities etc. Therefore, Kyai tries to make tabbhuwân Katoprak in style of santri which is more modern and interesting to conventional tabbhuwân. Most of TWS group members are young people taken from santri of Wali Sangan Islamic boarding school and some of them are alumni who are still associated to the school. At the beginning, the TWS is indeed founded as media of spreading Islam in Situbondo. Substantially, TWS uses media of historical story. Kyai's motivation is how to make young people in Situbondo progressive and not to be historical illiterate. Kyai thinks that modern culture has changed behavior and mindset of young generation in Situbondo so that it often causes destructive behavior. In this case, Kyai then handles it by establishing traditional art which tells about historical stories.

Giving Islamic education (dakwah) by means of cultural approach has been a common to do by Islamic boarding houses in Situbondo characterized by Islam NU (Nahdlatul 'Ulama). Since the era of K.H. As'ad Syamsul Arifin leadership (father of K.H. Khalil As'ad), Islamic boarding houses in Situbodo have used dakwah by means of culture like syi'ir in Madurese language (Hasan, 2016, pp. 36-37). Giving dakwah in aesthetic and performative style is considered to be more productive activities of dakwah rather than conventional method like sermon. People in Situbondo can accept aesthetic dakwah better rather than formal sermon (Hidayatullah, 2015, pp. 46-51, 2017, pp. 142-151) (Waris, Personal Communication, $10^{\text {rh }}$ Novemver 2018).

TWS is a traditional art performance which conveys cultural and Islam values aesthetically and performatively by means of historical stories. So far, TWS has played much role to develop culture in society. The important thing is instilling historical, religious and cultural values in society. Through TWS performance, people in remote villages in Situbondo can understand Islam, national and local history with pleasant way. History education which is conveyed by traditional art performance then will give interpretation of religious and cultural values. Historical stories of TWS are generally non-popular historical stories. Its aim is to make them not disappear in people's memory and to make people understand historical values which are almost forgotten for instances history of the prophet's companion, Salman Al-Farisi, history of national revolution and local history of Syeikh Maulana Ishaq which are less popular than history of the Wali Sanga. Therefore, besides to give history education to people, TWS also tries to conserve history in people's memory especially villagers in Situbondo.

TWS also plays a role to change mindset of people in village about tabbhuwân art. As explained before, tabbhuwân art is identical to gambling arena, drunk and liquor, woman sensualities etc. TWS exists to change those negative attitudes to be educative performance, as stated by Kiyai Kholil to Waris:

Why does èberrâ (a taste/midset) have to change, as said by Kyai? ètembhâng dâpadâ (compared to among) the same entertainment, nyarè (you look for entertainment) sè bâdâ olona, aolo ka kanjeng nabi, ta' bân saromben (with clear purpose, to look for connection to the prophet, not just kidding). Because it is not realism drama, not daily life, but history of the prophet's companion, tabiin and uncommon" (Waris, Personal Communication, $14^{\text {th }}$ July 2018).

The statement above explains Kyai's intention to make TWS performance to change mindset of people in village to look for entertainment which has clear purpose and to be useful. TWS generally aims places where its people considered to be undeveloped, doing many immoral things and difficult to educate by conventional way. This kind of people are usually difficult to accept dakwah by formal and conventional way. Therefore Kyai handles it by adapting aesthetic and performative way. For instance, when Kyai is invited to perform in a village, first Kyai will analyze social phenomena in that place. When in that village, there are many bad boys, so the Kyai will perform TWS with 
historical story of Uwais Al-Qurni which tells devotion of child to mother.

TWS also has a role to give a new nuance to treasure of Madurese traditional art in Situbodo. By means of its historical stories, its expressive form and its young players, TWS can give a new and progressive alternative entertainment which can build and develop cultural character of people in Situbondo. Therefore, TWS art is also called as entertainment and plays crucial role to develop history in society. They are giving education about history, conserving culture and instilling historical values to people.

TWS performance can be interpreted/receipted by audience especially Madurese people. People have plural interpretation. In Stuart Hall theory, audience interpretation is called by decode (Hall, 1999, pp. 507-517). Decode assumes active audience to interpret media which in this case is TWS performace. Decode is divided in three positions. The first is dominant-hegemonic position which means that audience justify meaning produced by TWS. In case of TWS performance, dominanthegemonic position signifies that audience have the same meaning with producer in historical story by TWS. The second is negotiation position which means that audience accept dominant meaning produced by TWS but they also give other interpretation of meaning produced. In case of TWS performance, negotiative position can be found in torture scene of protagonist character. In torture scene, audience do not interpret it by sympathy to protagonist actor but also by cheering, cursing and insulting antagonist character for being excessive to act. When those cheers are responded back by antagonist actor, its atmosphere then changes to be jokes, mocking each other between audience and antagonist character. The third is oppositional position which means that audience give interpretation in opposite way with meaning produced by TWS. In case of TWS performance, oppositional position can be seen in scenes of jokes or humor. In scene of humor, there is usally dialogue between joker and audience. When joker makes a statement, audience usually refute by making counter statement. The dialogue between joker and audience makes productive and exciting atmosphere.

\section{Conclusion}

Tabbhuwân Wali Sanga (TWS) is an effort of traditional Islamic boarding house to carry out educative mission to people in Situbondo. Conveying mission of dakwah, especially about history to young generation, is not that easy. By empowering human resources of santri who are teenagers, Wali Sanga Islamic boarding school initiates a traditional art performance with contemporary packaging by taking stories of Islam, national and local history lightly and adjusting them to local people knowledge. Therefore, TWS becomes media to convey history education to people.

To make it acceptable by local people, TWS does some creative process which are adaptation of form and culture. In stories of Islam, national and local history, its scripts played are taken from text of Al-Qur'an, Hadist and scientific books and words of Kyai. All of them is having process tashih/ correction from Kyai. Those scripts are adapted from written text to be text of drama performance. While its context of story is having transculture to be Madurese culture.

In TWS performance, there are some cultural and historical values which are: 1) pleasure values shown by actualization of expression by means of aesthetic experience of performers and audience; 2) vital values shown by patriotic values in stories with nationalism theme; 3) spiritual values shown in aesthetic forms of performance and mental building by means of Islamic stories; 4) Values of the Holy shown in its performance which have pedagogic character and invite people to interpret their spiritual experience.

\section{References}

Arifin, E. B. (dkk). (2008). Quo Vadis Hari Jadi Kabupaten Situbondo. Situbondo: Bappekap Situbondo Bekerjasama dengan Kopyawisda. Bertens, K. (1983). Filsafat Barat Dalam Abad XX, Inggris - Jerman. Jakarta: PT. Gramedia.

Bouvier, H. (2002). Lèbur!: Seni Musik dan Pertunjukan dalam Masyarakat Madura. Jakarta: Yayasan Obor Indonesia. 
Bustami, A. L. (2015). Resolusi Jihad: Perjuangan Ulama dari Menegakkan Agama Hingga Negara. Jombang: Pustaka Tebu Ireng.

Damono, S. D. (2012). Alih Wahana. Jakarta: Editum.

Guyanie, G. El. (2010). Resolusi Jihad Paling Syar'i. Yogyakarta: LKIS.

Hall, S. (1999). Encoding-Decoding. In S. During (Ed.), The Cultural Studies Reader Second Edition. London: Routledge.

Hasan, S. A. (2016). Kharisma Kiai As'ad di Mata Ulma. Bantul: Pusaka Pesantren.

Hidayatullah, P. (2015). Musik Adaptasi Dangdut Madura. Resital: Jurnal Seni Pertunjukan.

Hidayatullah, P. (2017). Panjhâk Sebagai Agen Pengembang Karakter Budaya dalam Masyarakat Madura di Situbondo. Jantra, 12(2), 139-151.

Husson, L. (1997). Eight centuries of Madurese migration to East Java. Asian and Pacific Migration Journal, 6(1), 77-102. https://doi. org/10.1177/011719689700600105

Jizarnah. (2018). Aktualisasi Pemahaman Nilai Menurut Max Scheler Bagi Masa Depan
Bangsa Indonesia. Journal Filsafat, 18(1).

Khalid, M. K. (2006). Karakteristik Peribidup Enam Puluh Sahabat Rasulullah. Bandung: Dipnegoro Press.

Koentjaraningrat. (1990). Sejarah Teori Antropologi II. Jakarta: UI Press.

Kurniawan, T. U. (2016). Perwujudan Naskah Drama Anusapati Karya S.H. Mintardja dalam Pementasan Teater. Journal of Urban Society's Arts. https://doi.org/10.24821/jousa. v3i2.1476

Nurcahyono, W. (2018). Penciptaan Teater "Jaka Kembang Kuning." Journal of Urban Society's Arts. https://doi.org/10.24821/jousa. v4i2.2164

Turino, T. (1999). Signs of Imagination, Identity, and Experience: A Peircian Semiotic Theory for Music. Ethnomusicology. https://doi. org/10.2307/852734.

\section{Informant}

Waris (60th years old). Script writer and director of TWS. 